\title{
Clonality of HTLV-1 differs between infected CD8+ T cells and infected CD4+ T cells in vivo
}

\author{
Anat Melamed ${ }^{1 *}$, Graham P Taylor ${ }^{2}$, Charles RM Bangham \\ From 16th International Conference on Human Retroviruses: HTLV and Related Viruses \\ Montreal, Canada. 26-30 June 2013
}

HTLV-1 selectively infects CD4+ T cells in vivo, with a minor population carried in CD8 $+\mathrm{T}$ cells. We previously established a method for the analysis of the clonality (clone frequency distribution) of infected cells by mapping and quantifying HTLV-1 proviral integration sites using high-throughput sequencing (Gillet et al, Blood, 2011; Cook et al, Blood, 2012; Melamed et al, PLoS Pathogens, 2013). To test the hypothesis that the clonality of HTLV-1 differs between infected CD8+ T cells and infected $\mathrm{CD} 4+\mathrm{T}$ cells in natural infection, we magnetically sorted CD4+ and CD8+ T cells from PBMCs of 12 HTLV-1-infected individuals: 6 patients with HAM/TSP and 6 asymptomatic HTLV-1 carriers. We then used our high-throughput sequencing technique to quantify HTLV-1 clonality in each cell population. The median proviral load in CD4+ T cells and CD8+ T cells was 12.3 copies (range 6.0-30.2) and 2.0 (1.1-6.2) copies per 100 cells, respectively. The median proportion of the load carried by the infected CD8+ cells was 5.0\% (2.3\%-35.3\%). Proviral load in CD8+ cells and in CD4+ cells significantly correlated with proviral load in total PBMC $\left(\mathrm{p}<10^{\wedge}-6\right.$ and $\mathrm{p}<10^{\wedge}-3$, respectively). The clone frequency distribution was significantly more oligoclonal in CD8+ cells than in CD4+ cells: infected CD8+ clones were significantly over-represented among the most abundant clones in the blood. We conclude that HTLV-1-infected $\mathrm{CD} 8+\mathrm{T}$ cells have a clonal distribution distinct from infected CD4+ cells. These results show that infected $\mathrm{CD} 8+\mathrm{T}$ cells contribute disproportionately to the high PVL seen in HTLV-1 infection in vivo.

'Section of Immunology, Imperial College London, Wright-Fleming Institute, Norfolk Place, London, UK

Full list of author information is available at the end of the article
Authors' details

'Section of Immunology, Imperial College London, Wright-Fleming Institute, Norfolk Place, London, UK. ${ }^{2}$ Section of Infectious Diseases, Imperial College London, Wright-Fleming Institute, Norfolk Place, London, UK.

Published: 7 January 2014

doi:10.1186/1742-4690-11-S1-P137

Cite this article as: Melamed et al:: Clonality of HTLV-1 differs between infected CD8+ T cells and infected CD4+ T cells in vivo. Retrovirology 2014 11(Suppl 1):P137.
Submit your next manuscript to BioMed Central and take full advantage of:

- Convenient online submission

- Thorough peer review

- No space constraints or color figure charges

- Immediate publication on acceptance

- Inclusion in PubMed, CAS, Scopus and Google Scholar

- Research which is freely available for redistribution
() Biomed Central 